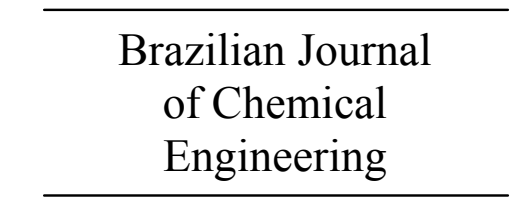

ISSN 0104-6632

Printed in Brazil

www.abeq.org.br/bjche

Vol. 30, No. 03, pp. 449 - 456, July - September, 2013

\title{
UTILIZATION OF ORANGE BAGASSE AND MOLOKHIA STALK FOR PRODUCTION OF PECTINASE ENZYME
}

\author{
S. A. Ahmed* and F. A. Mostafa \\ Department of Chemistry of Natural and Microbial Products, National Research Centre, \\ Phone: 00202 6347972, Fax: 00202 3370931, Dokki, Cairo, Egypt. \\ E-mail: dr_Sa_Ahmed@yahoo.com
}

(Submitted: December 17, 2011 ; Revised: July 3, 2012 ; Accepted: August 3, 2012)

\begin{abstract}
Studies were conducted on the production and extraction of exo-polygalacturonase (PG) in solidstate fermentation (SSF) using orange bagasse $(\mathrm{Ob})$ and molokhia stalks (Ms) as a new solid support by Penicillium pinophlilum Hedg 3503 NRRL. The parameters affecting PG production under SSF were optimized. The maximum PG activity of $\sim 3270 \mathrm{U} / \mathrm{g}$ dry solid substrate was obtained from P. pinophlilum Hedg 3503 NRRL grown for 7 days on $\mathrm{Ob}$ and Ms in the ratio 1:3 (w/w), moistened with distilled water at $68.2 \%$ initial moisture content. Highest enzyme titers occurred in SSF without added nutrients, indicating nutrient sufficiency of the $\mathrm{Ob}$ and MS mixture to sustain growth and a high level of pectic substances which induced PG production. The extraction of PG from the fermented biomass was optimized. Among the various solvents tested, the maximum level of enzyme activity was achieved when acetate buffer (0.05 M; pH 5.0) was used. The optimum volume of buffer was $50 \mathrm{~mL}$, an extraction time of $60 \mathrm{~min}$ was sufficient to extract most enzyme, which yielded 3269.6 U/g dry solid substrate of enzyme activity. Repeated washes under the optimum conditions showed that most of the enzyme (about 98\%) was recovered in three repeated extractions. Moreover, $68.9 \%$ of total activity was achieved in the first wash.

Keywords: Exo-polygalacturonase; Solid-state fermentation; Solid substrate.
\end{abstract}

\section{INTRODUCTION}

Pectins are high molecular weight acid polysaccharides, primarily made up of $\alpha-(1 \rightarrow 4)$ linked D-galacturonic acid residues with a small number of rhamnose residues in the main chain and arabinose, galactose and xylose in the side chain (Kumar et al., 2011). Pectinases constitute a group of enzymes which degrade the pectin present in most plants. Although several types can be found, polygalcaturonases are the most abundant and studied ones, representing around $25 \%$ of industrial enzymes sales (Jayani et al., 2005). Pectinase production has been reported from microorganisms including actinomycetes (Beg et al., 2000), yeast (Blanco et al., 1999) and fungi (Kumar et al., 2011). Pectinases are of significant importance in the current biotechnological area with their all-embracing applications in fruit juice extraction and clarification, scouring of cotton, degumming of plant fibers, waste water treatment, vegetable oil extraction, tea and coffee fermentations, bleaching of paper, in poultry feed additives and in the alcoholic beverage and food industries (Jayani et al., 2005; Jacob and Prema, 2006; Kumar et al., 2011). The genus Penicillium is known worldwide for production of secondary metabolites and extracellular enzymes of commercial value, including pectinases (Banu et al., 2010). Solid state fermentation (SSF) involves the growth of microorganisms on moist solid substrates in the absence (or near absence) of free water (Sharma et al., 2008). This technique offers the possibility of processing agro-

*To whom correspondence should be addressed 
industrial residues that can be used, for instance, as substrates for enzymes production, helping in this way to minimize the pollution by removing this waste and converting it to useful products. In Egypt more than a hundred orange juice factories are widespread and produce at least 40,000 tons of orange pulps and peels annually, as highly wet wastes (El-Sheekh et al., 2009). Utilization of orange-canning wastes was reported by some authors (Pagán et al. 2006; El-Sheekh et al. 2009). Orange bagasse is rich in pectic substances $(50.4 \%)$, so it is a good inducer of PG production. On the other hand, molokhia (Arabic common name) or Jew's Mallow (English common name) stalks agro waste from the plant (Corchorus olitorius) is cheap and abundantly available in Egypt. As far as we are aware, nothing has yet been reported on the use of molokhia plant in SSF. The aim of the current study was to investigate the production and extraction of exo-polygalacturonases by solid state fermentation using a mixture of orange bagasse (pulp and peels) and molokhia stalks.

\section{MATERIALS AND METHODS}

\section{Microorganism}

Penicillum pinophlilum Hedg 3503 NRRL used in this study was obtained from Northern Regional Research Laboratory (NRRL), Peoria, Illinois, USA. It was propagated on Potato -Dextrose-Agar (PDA) slants at $35{ }^{\circ} \mathrm{C}$ and transferred monthly. For shortterm storage, slants were maintained at $4{ }^{\circ} \mathrm{C}$.

\section{Inoculum}

For inoculum preparation, the microorganism grown on PDA for 5 days at $35^{\circ} \mathrm{C}$ was suspended in $20 \mathrm{~mL}$ sterilized distilled water in a $100 \mathrm{~mL}$ flask (under agitation with a magnetic stirrer).

\section{Preparation of Different Solid Substrates}

Orange bagasse (pressed mixture of pulp and peels), molokhia stalks, lemon peels, pea peels and watermelon peels were obtained from the local market in Egypt, cut into small pieces ( $\sim 2 \mathrm{~mm}$ long), washed with tap water several times in order to remove all water-soluble compounds and finally dried at $50{ }^{\circ} \mathrm{C}$ for $48 \mathrm{~h}$. Corn cobs, rice straw, sawdust and onion skins were dried and ground to about $2 \mathrm{~mm}$ in particle size. Wheat bran was dried and used in the fermentation process.

\section{Solid State Fermentation}

It was carried out using a $250-\mathrm{mL}$ Erlenmeyer flask containing $2 \mathrm{~g}$ from each previous solid substrate moistened with $15 \mathrm{~mL}$ of distilled water (initial $\mathrm{pH}$ 5.0) before sterilization. The production medium was inoculated with $1 \mathrm{~mL}$ of spore suspension (prepared as described above). The flasks were incubated in a rotary shaker $(150 \mathrm{rpm})$ at $35^{\circ} \mathrm{C}$ for 7 days.

\section{Moisture Content}

A known weight of each sample (dry orange bagasse or molokhia stalks) was heated at $105{ }^{\circ} \mathrm{C}$ till constant weight, the values were calculated on the dry basis (Ismail, 1995).

\section{Ash Content}

This was carried out according to the method of Abdel-Fattah et al. (1976). It was determined by heating solid substrate to constant weight at $800{ }^{\circ} \mathrm{C}$.

\section{Pectic Substance}

It was determined according to the method of Abdel-Fattah et al. (1976).

\section{Enzyme Extraction}

This was done according to the method of Xiros et al. (2008). After the fermentation period, the enzyme was extracted by suspending the fermented material $(10 \mathrm{~g})$ in $50 \mathrm{~mL}$ distilled water $(1: 5 \mathrm{w} / \mathrm{v})$ and shaking $(150 \mathrm{rpm})$ for $1 \mathrm{~h}$ at $35^{\circ} \mathrm{C}$. Following extraction, the suspended materials and fungal biomass were separated by centrifugation at $5000 \mathrm{rev} / \mathrm{min}$ for $20 \mathrm{~min}$ at $4{ }^{\circ} \mathrm{C}$. The clarified supernatant was used as the source of the crude enzyme.

\section{Assay of Polygalacturonase Activity}

This was performed according to the method of Silva et al. (2005). Exo-polygalacturonase (exo-PG) activity was evaluated by mixing $0.2 \mathrm{~mL}$ of enzymatic extract and $0.8 \mathrm{~mL}$ of citrus pectin solution $(0.5 \% \mathrm{w} / \mathrm{v}$ pectin in $0.05 \mathrm{M}$ acetate buffer, $\mathrm{pH} 5.0)$. Samples were incubated at $50{ }^{\circ} \mathrm{C}$ for $10 \mathrm{~min}$ and the reducing sugar was determined by Somogyi method (1952). One unit of exo-PG activity was defined as the amount of enzyme releasing $1 \mu \mathrm{mol}$ of reducing sugars (as galacturonic acid) per min per $\mathrm{mL}$ of enzyme solution. 


\section{RESULTS AND DISCUSSION}

\section{Enzyme Production by Solid State Fermentation}

Polygalacturonase (PG) is generally considered to be synthesized in the presence of an inducer. Due to the composition of orange bagasse $(\mathrm{Ob})$, which contains pectin substance $(50.4 \%)$, protein $(5.1 \%)$, ash $(4.0 \%)$ and moisture (4.0\%), it was selected and tested initially alone as a solid substrate for the production of PG. Penicillium pinophilum Hedg NRRL 3503 was capable of growing on $\mathrm{Ob}$ as substrate in SSF, and produced PG in the absence of supplemented nutrients only with distilled water as moistening agent. Enzyme production by SSF in a rotary shaker (to prevent the solid substrate from agglomerating) was analyzed during 11 days, indicated that maximum PG activity $(82.23 \mathrm{U} / \mathrm{g}$ dry solid substrate) was obtained after 7 days, thereafter the enzyme activity declined (data not shown). Similar observation was reported for the production of pectinase and cellulase by fungi on SSF (Desgranges and Durand, 1990). However, when the time was increased or decreased to other than 7 days, the production of PG gradually decreased. This might be due to the fact that cultivation of fungi for an extra time could affect the $\mathrm{pH}$ of the medium, which may favour a limited growth rate and PG production by reducing accessibility of pectic substances (Arabi et al., 2011). The activity obtained in this study was very high compared to those reported for pectinolytic strains such as Penicillium frequentans (3.4 U/g dry ss), Aspergillus niger ( $25 \mathrm{U} / \mathrm{g}$ dry ss), Penicillium viridicatum RFC3 (12 U/g dry ss) and Penicillium sp. (64.5 U/ g dry ss), (Garzón and Hours, 1992; Castilho et al., 1999, Silva et al., 2002 and Patil and Chaudhari, 2010). The results showed that SSF was suitable for pectinase production by $P$. pinophilum Hedg NRRL 3503 using agricultural and agro industrial wastes. Orange bagasse has been used as a fermentable substrate to induce pectinase production by some authors (Silva et al., 2005 and El-Sheekh et al., 2009).

\section{Orange Bagasse Loading}

Study the effect of orange bagasse $(\mathrm{Ob})$ quantity on the production of $\mathrm{PG}$ (with the same ratio of solid to liquid) is presented in Figure 1. The results indicated that $1 \mathrm{~g} \mathrm{Ob}$ was sufficient as a rich medium for the highest PG yield (139.13 U/ g dry ss), which represented $69.20 \%$ increase in enzyme production compared with control. Giese et al. (2008) found that orange bagasse at a solids concentration of $16 \%(\mathrm{w} / \mathrm{v})$ was sufficient to sustain Botryosphaeria rhodina MAMB-05 and produced high pectinase titres.

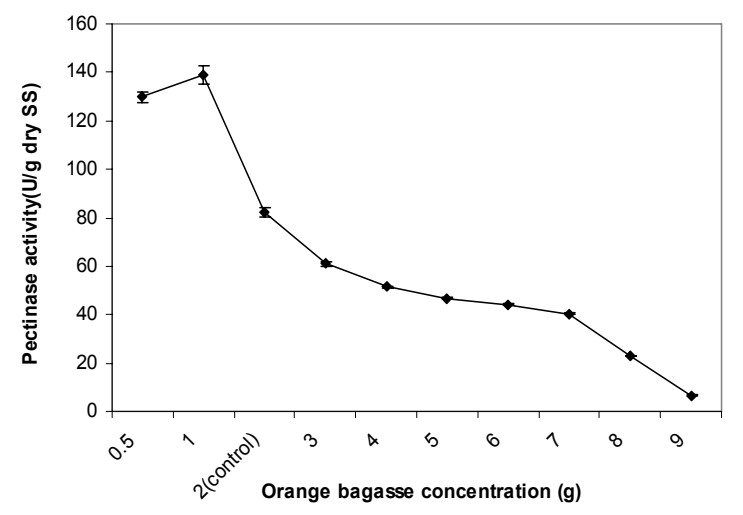

Figure 1: Effect of orange bagasse concentration on the production of pectinase enzyme by the solid state fermentation technique.

\section{Supplementation with Natural Substrates}

Orange bagasse constitutes an excellent inducer substrate for PG production by $P$. pinophilum Hedg NRRL 3503 under SSF. It was supplemented with an equal amount of different natural substrates, i.e., lemon peels (Lp), onion skins (Os), watermelon peels $(\mathrm{Wp})$, pea peels $(\mathrm{Pp})$, wheat bran $(\mathrm{Wb})$, sawdust (Sd), corn cobs $(\mathrm{Cc})$, rice straw (Rs) and molokhia stalks (Ms). Among all agricultural wastes and agro-industrial by-products tested $(50 \% \mathrm{w} / \mathrm{w})$, the $\mathrm{Ob}$ and $\mathrm{Ms}$ mixture was the most suitable for maximal PG production (616.86 U/g dry ss) without nutrients addition. However, it is interesting to notice that no previous studies have been reported on enzyme production using $\mathrm{Ms}$ as solid substrate. Besides, the efficiency of enzyme production depended on the bare chemical composition of the raw material, accessibility of various components and their chemistry or physical association. Molokhia plant is an annual herb in the Middle East and dry samples are rich in mineral salt (16.45\%) such as iron, phosphorus, calcium, sodium, magnesium, potassium, etc. Moreover, Molokhia contains pectic substance $(21.20 \%)$, protein $(22.0 \%)$, ash $(18.0 \%)$, moisture $(10.0 \%)$, fat, fiber and vitamins (vitamins A, B ...etc). From the results presented in Figure 2, it may be concluded that addition of some agricultural wastes to $\mathrm{Ob}$ improved the production of PG. Silva et al. (2002) reported that, among all agricultural wastes and agro-industrial by-products, an orange bagasse and wheat bran mixture $50 \%(\mathrm{w} / \mathrm{w})$ was the most proper for the maximal pectin lyase production in SSF cultures of Penicillium viridicatum Rfe3. 


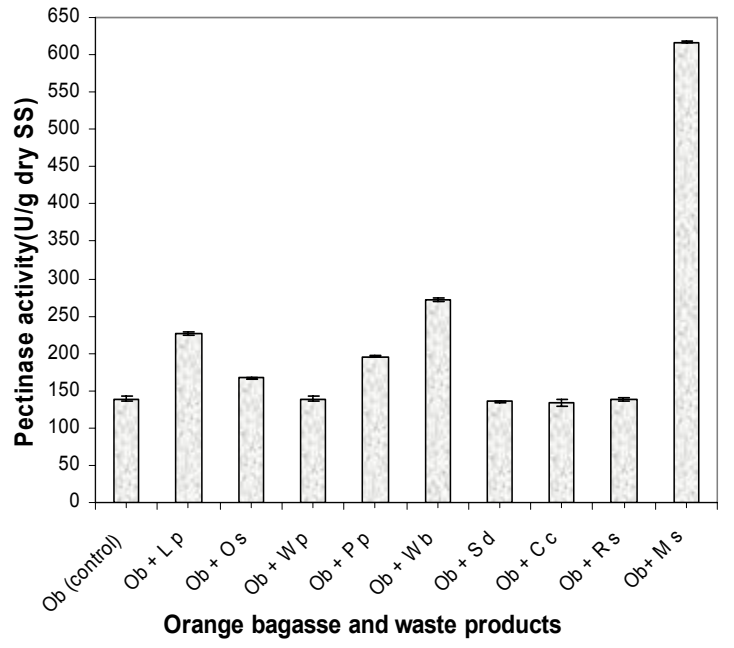

Lemon peels (Lp), onion skin (Os), watermelon peels (Wp), pea peels $(\mathrm{Pp})$, wheat bran $(\mathrm{Wb})$, sawdust $(\mathrm{Sd})$, corn cob $(\mathrm{Cc})$, rice straw (Rs) and molokhia stalk (Ms).

Figure 2: Effect of mixing of orange bagasse with different waste products $(0.5 / 0.5 \mathrm{w} / \mathrm{w})$ on the production of pectinase enzyme.

\section{Effect of Different Ob and Ms Ratio}

In the comparative studies, mixed substrate fermentation was carried out using $\mathrm{Ob}$ and $\mathrm{Ms}$ with different ratios (Figure 3). The mixture which contained one part of $\mathrm{Ob}$ and three parts of $\mathrm{Ms}$ showed a significant increase in enzyme yield (111.94\%).

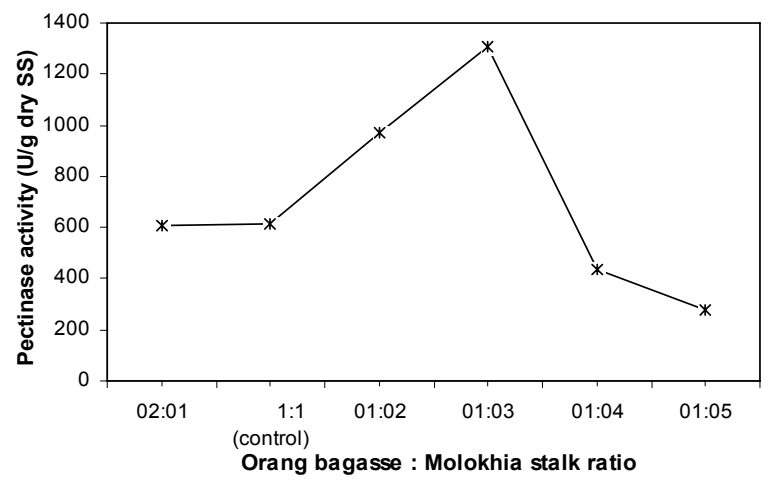

Figure 3: Effect of different ratios (w/w) of orange bagasse and molokhia stalks on the production of pectinase enzyme by the SSF technique.

The production of PG was enhanced up to 2.12 times when one part of $\mathrm{Ob}$ and three parts of Ms was used as carbon source compared with the control (1Ob:1 Ms). Increasing the Ms quantity stimulated fungal growth and PG production, this result may be due to its composition (pectic substance, protein, mineral salts, vitamins, etc.). High levels of exo-PG, xylanase or CMC-ase activities can be obtained using a mixture of grape pomace and orange peels (1:1) in SSF (Díaz et al., 2012).

\section{Effect of Supplementation with Synthetic Carbon Sources}

Addition of different carbon sources (sucrose, glucose, galactose, lactose and carboxymethyl cellulose (CM-cellulose) on an equal carbon basis was studied and highlighted in Figure 4(a). The enzyme production was strongly repressed in the presence of lactose, showing only $27.34 \%$ relative activity. Generally, all C-sources tested did not enhance enzyme production, this might be due to the effect of inducible substrate type ( $\mathrm{Ob}$ and $\mathrm{Ms}$ ) on the production of PG by the fungal strain. On the other hand, supplementation with other C-sources repressed the production of $\mathrm{PG}$, which is induced and controlled by a feedback mechanism. The supplementation of the production medium with glucose or CM-cellulose resulted in a marked decrease in enzyme activity, reaching about 33.81 and $59.84 \%$, respectively of PG as compared to the control. This result is in accordance with similar observations of Phutela et al. (2005), who supplemented SSF with different C-sources (glucose, CM-cellulose and galactose). They mentioned that PG was strongly repressed by the addition of these C-sources. However, this result is in contrast to that obtained by Solis-Pereira et al. (1993), who reported that supplementation of a culture medium containing pectin with glucose, sucrose or galacturonic acid (up to $10 \%$ ) did not reduce PG production.

\section{Effect of Supplementation with Nitrogen Sources}

The results in Figure 4(b) showed that supplementation with nitrogen sources, on an equal nitrogen basis, did not enhance the fungal growth and hence the production of PG enzyme. The proteins in Ms and $\mathrm{Ob}$ (22.0 and $5.1 \%$ in dry samples, respectively) provide the production media with the nitrogen needed for fungal growth and enzyme production. On the other hand, enzyme production was strongly inhibited by $88.0 \%$ in the presence of peptone. Phutela et al. (2005) reported that the presence of yeast extract and ammonium sulfate supported maximal production of pectinase, followed by malt sprouts and ammonium sulfate. Kumar et al. (2011) showed that ammonium sulfate was the best inducer of pectinase in Aspergillus niger MCIM 548 using SSF process. 


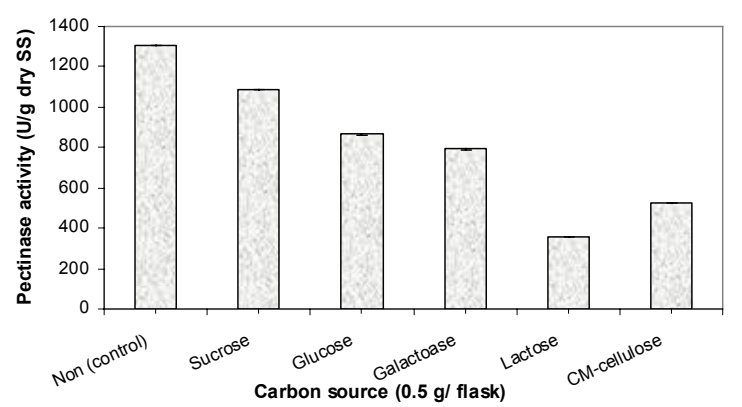

(a)

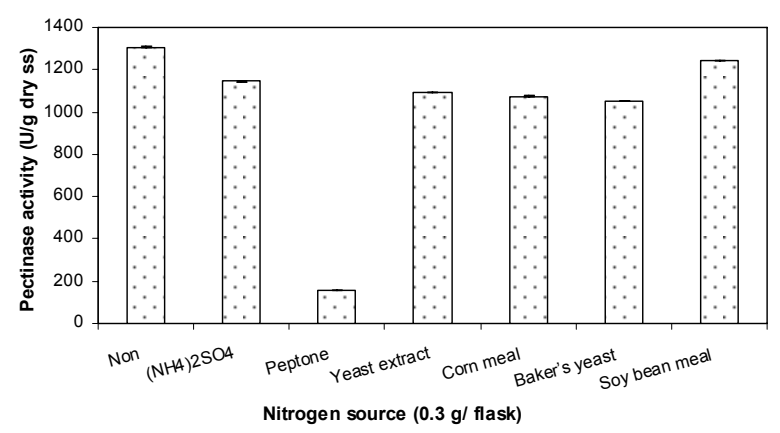

(b)

Figure 4: Effect of supplementation (a) with synthetic carbon sources on an equal carbon basis; (b) with different nitrogen sources on an equal nitrogen basis on the production of pectinases by P. pinophilum. The control culture in both cases was Orange bagasse and Molokhia stalks (ratio 1:3 w/w).

\section{Effect of Initial Moisture Content on Enzyme Production}

An optimum moisture level has to be maintained as lower moisture tends to reduce nutrient diffusion, microbial growth, enzyme stability and substrate swelling (Xiros et al., 2008). The existence of an optimum moisture content of the medium has profound effects on growth kinetics, and on the physicochemical properties of solids, which in turn affects productivities (Lonsane et al., 1992). The moisture level of $68.2 \%$ yielded the highest PG activity of $1307.37 \mathrm{U} / \mathrm{g}$ dry ss (data not shown). This result is near to that obtained by Kumar et al. (2011) for optimum production of Aspergillus niger NCIM 548 pectinase using SSF with $70 \%$ moisture content. A high moisture content has negative consequences for growth, as the porosity of the medium and oxygen diffusion were reduced when lignocellulosic substrates were used as the C-source in SSF (Silva et al., 2005). As reported by Xiros et al. (2008), moisture content affects heat and mass transfer inside the culture. Higher moisture content may influence $\mathrm{O}_{2}$ transfer rates by affecting the bed depth and lead to particle agglomeration of the moist fermenting solids. However, low moisture levels are known to decrease the metabolic and enzymatic activity, probably due to reduced solubility of nutrients from the solid substrate, low substrate swelling and higher water tension (Uyar and Baysal, 2004, Arabi et al., 2011).

\section{Effect of Solvent Type on Enzyme Extraction}

The extraction efficiency is critical to the recovery of the enzyme from the fermented biomass, hence selection of a suitable solvent is necessary. Different solvents selected for this study were acetate buffer, Tween 80 , Tween 40 , glycerol and polyethylene glycol (PEG). It is clear that among all the extractants employed (Figure 5), acetate buffer $(0.05 \mathrm{M} ; \mathrm{pH} 5.0)$ gave the best result and was found to be efficient in recovering PG from fermented solid (about 2.44 times as compared with control). Our results are in agreement with the observation of Castilho et al. (2000), who also found that acetate buffer ( $\mathrm{pH}$ 4.4) extracted pectinases from wheat bran by Aspergillus niger better than glycerol or distilled water. Adsorption of the enzyme to cells or solid substrates has been attributed to ionic bond, hydrogen bond and Van der Waal's forces (Agrawal et al., 2005). Extraction increased with buffer as compared to distilled water probably due to the salting-in effect of the salt. Some enzymes produced under SSF have been recovered from the solid phase by treatment with distilled water (Silva et al., 2005; Patil and Chaudhari, 2010), de-ionized water (Giese et al., 2008), surfactant Tween 80 (Rezende et al., 2002) and buffer (Rezende et al., 2002; Phutela et al., 2005; Linde et al., 2007).

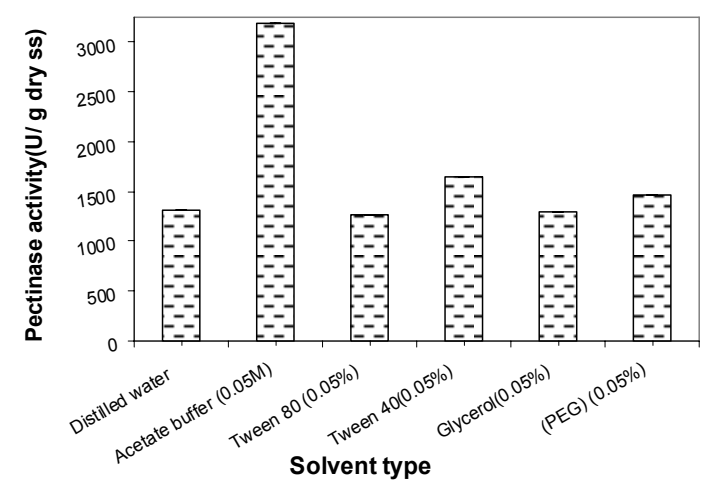

Figure 5: Effect of solvent type on the extraction of pectinase enzyme from fermented material $(\mathrm{Ob}$ and Ms). 
Effect of Buffer Molarity on Enzyme Extraction

Extraction was performed with acetate buffer ( $\mathrm{pH}$ 5.0 ) of varying molarity as extractant. The recovered activity increased with increasing molarity up to $0.05 \mathrm{M}$ (data not shown). Above and below this value the enzyme yield was negatively affected due to the salting-in effect of the salt. Aikat and Bhattacharyya (2000) reported that the extraction of protease from fermented wheat bran by Rhizopous oryzae increased with potassium phosphate buffer molarity.

\section{Effect of Buffer Volume on Enzyme Extraction}

The volume of buffer $(0.05 \mathrm{M}$; $\mathrm{pH}$ 5.0) was varied from 25 to $200 \mathrm{~mL}$ for $10 \mathrm{~g}$ of fermented material (data not shown). It was found that the amount of extracted enzyme increased with the increase of buffer volume. Enzyme activity increased up to $100 \mathrm{~mL} / 10 \mathrm{~g}$ fermented material, where the PG recovery was about 1.03 times that using $50 \mathrm{~mL}$ buffer). More buffer released more enzyme from the fermented material. The solvent volume must be sufficient for complete enzyme extraction. Excessively large volume of buffer used for greater extraction would also yield an enzyme solution too dilute to be profitably utilized (Aikat and Bhattacharyya, 2000). There was a decrease in total activity when a lower volume of buffer was used for extraction. This might be due to insufficient solvent volume to penetrate the solid fermented mass.

\section{Effect of Soaking Time on Enzyme Extraction}

Soaking of the fermented substrate with acetate buffer $(10 \mathrm{~g} / 100 \mathrm{~mL})$ was done for different periods, varying from 30 to $150 \mathrm{~min}$. The maximum amount of PG was extracted after 60 min (Figure 6). A longer soaking period did not result in a significant gain in recovery. Other studies reported that the time required to remove enzymes from a solid substrate was ranged from $30 \mathrm{~min}$ (Castilho et al., 2000) to $48 \mathrm{~h}$ under shaking conditions (Shata, 2005).

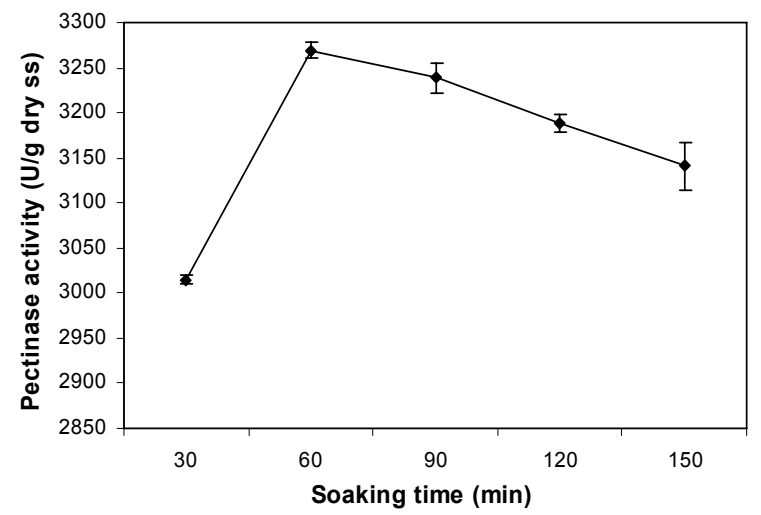

Figure 6: Effect of soaking time on the extraction of pectinase enzyme from fermented material $(\mathrm{Ob}$ and Ms).

\section{Repeated Extractions of PG Enzyme}

Repeated extractions were carried out more as a confirmatory test in order to determine whether most of the PG could be recovered in one extraction. This parameter was optimized by adding a fresh aqueous extractant after the extraction for each wash. Four consecutive extractions were performed and the results are presented in Table 1. About $68.93 \%$ $(326.96 \mathrm{U} / \mathrm{mL})$ of total activity was obtained from the first extraction. Considering that $100 \%$ of the enzyme could be extracted with only four extractions, $97.79 \%$ (463.86 U/ mL) of PG was recovered from fermented material during three extractions. Shata (2005) reported that four repeated extractions are sufficient for maximum enzyme recovery from solid fermented medium.

Table 1: Repeated extraction of pectinase enzyme from fermented material (1: $10 \mathrm{w} / \mathrm{v}) \mathrm{ratio}$.

\begin{tabular}{|l|c|c|c|c|c|c|}
\hline $\begin{array}{c}\text { Number of recovery } \\
\text { stage }\end{array}$ & $\begin{array}{c}\text { Pectinase } \\
\text { activity } \\
\text { (U/ mL) }\end{array}$ & $\begin{array}{c}\text { Pectinase } \\
\text { activity } \\
\text { (U/ g ss) }\end{array}$ & $\begin{array}{c}\text { Pectinase } \\
\text { activity } \\
\text { (U/ g ss) \% }\end{array}$ & $\begin{array}{c}\text { Cumulative } \\
\text { enzyme } \\
\text { activity } \\
\text { (U/ mL) \% }\end{array}$ & $\begin{array}{c}\text { Cumulative } \\
\text { enzyme } \\
\text { activity } \\
\text { (U/g dry ss) }\end{array}$ & $\begin{array}{c}\text { Cumulative } \\
\text { enzyme } \\
\text { activity } \\
\text { (U/ mL) \% }\end{array}$ \\
\hline First washing & 326.96 & 3269.56 & 68.93 & 326.96 & 3269.56 & 68.93 \\
Second washing & 85.09 & 850.89 & 17.94 & 412.05 & 4120.45 & 86.86 \\
Third washing & 51.81 & 518.07 & 10.92 & 463.86 & 4638.52 & 97.79 \\
Fourth washing & 10.50 & 105.00 & 2.21 & 474.36 & 4743.52 & 100.00 \\
\hline
\end{tabular}




\section{CONCLUSIONS}

In conclusion, we report the successful utilization of the agro industrial wastes Orange bagasse $(\mathrm{Ob})$ and Molokhia stalks (Ms) for the production of polygalacturonase (PG) from $P$. pinophlilum Hedg 3503 NRRL under solid state fermentation technique in the absence of supplemented nutrients, only with distilled water as moistening agent. To the best of our knowledge, this is the first report on using molokhia stalks as a solid substrate for $\mathrm{PG}$ production. A mixture of $\mathrm{Ob}$ and $\mathrm{Ms}$ (1:3 ratio) is the most suitable substrate for fungal growth and $P G$ induction due to its composition of pectic substance. Optimization of the production and extraction parameters increased the enzyme yield from 82.23 to $3269.60 \mathrm{U} / \mathrm{g}$ dry ss. Most of the enzyme (about $98 \%$ ) was recovered by three repeated extractions. Moreover, $68.9 \%$ of the total activity $(326.9 \mathrm{U} / \mathrm{mL}$ ) was obtained in the first wash. It is therefore important to use agro industrial wastes like $\mathrm{Ob}$ and Ms as low-cost fermentable substrates in the biotechnological sector.

\section{ACKNOWLEDGEMENT}

The authors sincerely thank Prof. Ahmed F. Abdel-Fattah and Prof. Mohamed Farid from Department of Chemistry of Natural and Microbial Products (N. R. C., Egypt.) for providing help and reviewing this work.

\section{REFERENCES}

Abdel-Fattah, A. F., Mabrouk, S. S., Edrees, M. and Shaulkamy, M. S., Studies of the polysaccharides from sunflower heads. Carbohydrate Research, 50, 109-113 (1976).

Agrawal, D., Patidar, P., Banerjee, T. and Patil, S., Alkaline protease production by a soil isolate of Beauveria feling under SSF condition: Parameter optimization and application to soy protein hydrolysis. Process Biochemistry, 40, 1131-1136 (2005).

Aikat, K. and Bhattacharyya, B. C., Protease extraction in solid state fermentation of wheat bran by a local strain of Rhizopus oryzae and growth studies by the soft gel technique. Process Biochemistry, 35, 907-914 (2000).

Arabi, M. I. E., Jawhar, M. and Bakri, Y., Effect of additional carbon source and moisture level on xylanase production by Cochlibolus sativus in solid fermentation. Microbiology, 80, (2), 150153 (2011).

Banu, A. R., Devi, M. K., Gnanaprabhal, G. R., Pradeep, B. V. and Palaniswamy, M., Production and characterization of pectinase from Penicillium chrysogenum. Indian Journal of Science and Technology, 3, (4), 377-381 (2010).

Beg, Q. K., Bhushan, B., Kapoor, M. and Hoondal, G. S., Effect of amino acids on production of xylanase and pectinase from Streptomyces sp. QG-11-3. World Journal of Microbiology Biotechnology, 16, 211-213 (2000).

Blanco, P., Sieiro, C. and Villa, T. G., Production of pectic enzymes in yeast. FEMS Microbiol. Lett., 175, 1-9 (1999).

Castilho, L. R., Alves, T. L. M. and Medronho, R. A., Recovery of pectinolytic enzymes produced by solid state culture of Aspergillus niger. Process Biochemistry, 34, 181-186 (1999).

Castilho, L. R., Medronho, R. A. and Alves, T. I., Production of pectinase obtained by solid-state fermentation of agro-industrial residues with Aspergillus niger. Bioresources Technology, 71, 45-50 (2000).

Desgranges, C. and Durand, A., Effect of $\mathrm{pCO}_{2}$ on growth condition and enzyme production in solid state fermentation of Aspergillus niger and Trichoderma viride TS. Enzyme Microbial Technology, 2, 546-551 (1990).

Díaz, A. B., de Ory, I., Caro, I. and Blandino, A., Enhance hydrolytic enzymes production by Aspergilus awamori on supplemented grape pomace. Food and Bioproducts Processing, 90, (1), 72-78 (2012).

El-Sheekh, M. M., Ismail, Abdel-Mohsen, S., El-Abd, M. A. and Hegazy, E. M., Effective technological pectinases by Aspergillus carneus NRC1 utilizing the Egyptian orange juice industry scraps. International Biodeterioration and Biodegradation, 63, 12-18 (2009).

Garzón, C. G. and Hours, R. A., Citrus waste: An alternative substrate for pectinase production in solid state culture. Bioresources Technology, 39, 93-95 (1992).

Giese, E. C., Dekker, R. F. H. and Barbosa, A. M., Orange bagasse as substrate for the production of pectinase and laccase by Botryoshaeria rhodina MAMB-05 in submerged and solid state fermentation. BioResources, 3, (2), 335-345 (2008).

Ismail, A-M., S. Utilization of orange peels for the production of multienzyme complex preparation by some fungal strains. Egyptian Journal of Science, 10, (4), 354-368 (1995).

Jacob, N. and Prema, P., Influence of mode of 
fermentation on production of polygalacturonase by a novel strain of Streptomyces lydicus. Food Technology Biotechnology, 44, 263-267 (2006).

Jayani, R. S., Saxena, S. and Gupta, R., Microbial pectinolytic enzymes: A review. Process Biochemistry, 40, 2931-2944 (2005).

Kumar, D. P., Thangabalan, B., Rao, P. V. and Yugandhar, N. M., Production of pectinase enzyme by Aspergillus niger using Ficus religiosa leaves in solid state fermentation. International Journal of Pharmacy and Technology, 3, (1), 1351-1359 (2011).

Linde, G. A., Magagnin, G., Costa, J. A. V., Bertolin, T. E. and Colauto, N. B., Column bioreactor use for optimization of pectinase production in solid substrate cultivation. Brazilian Journal of Microbiology, 38, 557-562 (2007).

Lonsane, B. K., Saycedo-Castaneda, S., Raimbault, M., Roussos, S., Viniegra-Gonzalez, G., Ghildyal, N. P., Ramakrishna, M. and Krishnaiah, M. M., Scale-up strategies for solid-state fermentation system. Process Biochemistry, 27, 259-273 (1992).

Pagán, A., Conde, J., Ibarz, A. and Pagán, J., Orange peel degradation and enzyme recovery in the enzymatic peeling process. International Journal of Food Science and Technology, 41, 113-120 (2006).

Patil, N. P. and Chaudhari, B. L., Production and purification of pectinase by soil isolate Pencillium sp. and search for better agro-residue for its SSF. Recent Research in Science and Technology, 2, (7), 36-42 (2010).

Phutela, U., Dhuna, V., Sandhu, S. and Ghadha, B. S., Pectinase and polygalacturonase production by thermophilic Aspergillus fumigatus isolated from decomposting orange peels. Brazilian Journal of Microbiology, 36, 63-69 (2005).

Rezende, M. I., Barbosa, A. de M., Vasconcelos, A. F. D. and Endo, A. S., Xylanase production by
Trichderma harzianum RIFAI by solid state fermentation on sugar cane bagasse. Brazilian Journal of Microbiology, 33, 67-72 (2002).

Sharma, A., Vivekanand, V. and Singh, R., Solid state fermentation for gluconic acid production from sugar cane molasses by Aspergillus niger ARNU-4 employing tea waste as the novel solid support. Bioresources Technology, 99, 3444-3450 (2008).

Shata, H. M. A., Extraction of milk-clotting enzyme produced by solid state fermentation of Aspergillus oryzae. Polish Journal of Microbiology, 54, (3), 241-247 (2005).

Silva, D., Martins, E. S., da Silva, R., Gomes, E., Pectinase production by Penicillium viridicatum RFC3 by solid state fermentation using agricultural wastes and agro-industrial by-products. Brazilian Journal of Microbiology, 33, 318-324 (2002).

Silva, D., Tokuioshi, K., Martins, E. S., da Silva, R. and Gomes, E., Production of pectinase by solidstate fermentation with Penicillium viridicatum RFC3. Process Biochemistry, 40, 2885-2889 (2005).

Solis-Pereira, S., Favela-Torres, E., Viniegra-Gonzalez, G. and Gutierrez-Rojas, M., Effect of different carbon sources on the synthesis of pectinase by Aspergillus niger in submerged and solid state fermentations. Applied Microbiology and Biotechnology, 39, 36-41 (1993).

Somogyi, N., Notes on sugar determination. Journal Biological Chemistry, 195, 19-23 (1952).

Uyar, F. and Baysal, Z., Production and optimization of process parameters for alkaline protease production by a newly isolated Bacillus sp. under solid state fermentation. Process Biochemistry, 39, 1893-1898 (2004).

Xirox, C., Topakas, E., Katapodis, P. and Christakopoulos, P., Hydrolysis and fermentation of brewer's spent grain by Neurspora crassa. Bioresources Technology, 99, 5427-5435 (2008). 